\author{
(2) (1) $\Theta$ \\ Jurnal Pendidikan Dasar Indonesia is licensed under \\ A Creative Commons Attribution-Non Commercial 4.0 International License
}

\title{
Peningkatan Kreativitas Peserta Didik Dalam Pembelajaran Tematik Di Kelas I SEKolah DASAR Negeri 24 SUNGai PINYUH
}

\author{
Uray Zuraida \\ Sekolah Dasar Negeri 24 Sungai Pinyuh,Kabupaten Mempawah, Kalimantan Barat \\ E-mail: ekamurdani@gmail.com
}

\begin{abstract}
Abstrak: Penelitian ini bertujuan untuk mendeskripsikan peningkatan kreativitas peserta didik pada pembelajaran tematik di kelas I SD Negeri 24 Sungai Pinyuh. Metode penelitian yang digunakan adalah metode penelitian deskriptif dengan bentuk penelitiannya adalah Penelitian Tindakan Kelas (PTK). Berdasarkan perhitungan persentase rata-rata 3 kreativitas peserta didik berupa menafsirkan gambar/cerita, senang melibatkan diri dalam tugas-tugas dan bekerja lebih cepat diperoleh sebesar 54,2\% pada siklus I dan 68,3\% pada siklus II. Hasil ini memperlihatkan bahwa kreativitas peserta didik dari siklus I ke siklus II mengalami peningkatan sebesar $14,2 \%$. Sehingga dapat disimpulkan bahwa pembelajaran tematik dapat meningkatkan kreativitas peserta didik kelas I SDN 24 Sungai Pinyuh.
\end{abstract}

Kata Kunci: penelitian tindakan kelas, kreativitas, tematik, sekolah dasar.

\section{Pendahuluan}

Peningkatan sumber daya manusia dalam era globalisasi dan era reformasi menunjukkan betapa pentingnya kreativitas untuk dikelola dan dikembangkan secara optimal. Oleh karena itu perlu dikembangkan iklim belajar mengajar yang baik bagi berkembangnya potensi kreatif peserta didik sehingga yang bersangkutan mampu menghadapi dan memecahkan permasalahan yang dihadapi dalam kehidupan sehari-hari saat ini maupun yang akan datang. Jika sedari dini kreativitas sudah dikembangkan pada diri peserta didik maka kelak dalam dirinya akan terbentuk pribadi yang kreatif, merasa siap dan mampu menyesuaikan diri dengan segala perubahan yang terjadi pada lingkungannya.

Kreativitas dapat membentuk peserta didik untuk mempunyai keterampilan berpikir lancar (bekerja lebih cepat dari pada anak-anak yang lain), keterampilan berpikir luwes (mampu menafsirkan suatu gambar/cerita), merasa tertantang untuk maju (senang melibatkan diri dalam tugastugas). Kenyataan di SDN 24 Sungai Pinyuh pembelajaran tematik di kelas I terkesan konvensional/berfokus pada guru, kurang melibatkan peserta didik dalam berintereaksi, kurang memberikan bimbingan, sehingga peserta didik pasif berkomunikasi, kurang merespon pelajaran, kurang kooperatif, peserta didik tidak merasa senang dan tertarik/jenuh. Hal ini mengakibatkan kreativitas peserta didik belum mengalami peningkatan. Dari pengamatan awal anak yang dapat memberikan penafsiran terhadap suatu gambar atau cerita $50 \%$, senang melibatkan diri dalam tugastugas $60 \%$ dan bekerja lebih cepat $30 \%$.
Berdasarkan data pengamatan awal tersebut menunjukkan bahwa kreativitas peserta didik masih rendah. Untuk mengatasi kelemahan tersebut di atas diperlukan suatu model pembelajaran tematik yang mampu meningkatkan kreativitas peserta didik.

Menurut Conny R. Semiawan dalam Reni Akbar (2001:4), mengemukakan bahwa kreativitas merupakan kemampuan untuk memberikan gagasan baru dan menerapkannya dalam pemecahan masalah. Utami Munandar (2009:25) kreativitas sebagai kemampuan umum untuk menciptakan sesuatu yang baru, sebagai kemampuan untuk memberikan gagasan-gagasan baru yang dapat diterapkan dalam pemecahan masalah.

Menurut Moreno dalam Daryanto (2009:146) menjelaskan bahwa yang penting dalam kreativitas bukanlah penemuan sesuatu yang belum pernah diketahui orang sebelumnya, melainkan bahwa produk kreativitas itu merupakan sesuatu yang baru bagi diri sendiri dan tidak harus merupakan sesuatu yang baru bagi orang lain atau dunia pada umumnya.

Menurut Guilford, dalam Ingridwati Kurnia (2007:5), menyatakan bahwa kreativitas mengacu pada kemampuan yang menandai ciri-ciri seorang kreatif. Salah satunya adalah kemampuan berpikir divergen. Kemampuan berpikir divergen merupakan kemampuan individu untuk mencari berbagai alternatif jawaban terhadap suatu persoalan. Guilford menekankan bahwa orang-orang kreatif lebih banyak memiliki cara berpikir divergen daripada konvergen (cara berpikir individu yang menganggap hanya ada satu alternatif jawaban dari suatu permasalahan). 
Menurut Brian Clegg \& Paul Birch (2001:6) Kreativitas merupakan istilah umum untuk hal-hal yang berkaitan dengan artistik contoh menulis buku, melukis, menggubah musik. Kreativitas penemuan suatu konsep, produk baru dan kreativitas humor memandang dunia dari sudut pandang yang berbeda. Pendapat Jeff De Graff \& Khaterine (2002) menyatakan bahwa icreativity is core of all competencies of your organization because creativity is what makes something better or new. Sedangkan menurut pendapat Cameron (dalam Elaine B. Johnson, 2006:213). Kreativitas adalah ciptaan alami kehidupan, diri kita sendiri adalah ciptaan, kita ditakdirkan untuk meneruskan, kreativitas dengan menjadikan diri kita kreatif.

Pendapat S.C. Utami Munandar dalam Reni Akbar (2001:4), pengertian kreativitas sebagai berikut : (1) Kreativitas adalah kemampuan untuk membuat kombinasi baru berdasarkan data, informasi, atau unsur-unsur yang ada, (2) Kreativitas (berpikir kreatif atau divergen) adalah kemampuan berdasarkan data atau informasi yang tersedia menemukan banyak kemungkinan jawaban terhadap sesuatu masalah dimana penekanannya pada kuantitas, ketepatgunaan, dan keragaman jawaban, (3) Secara operasional kreativitas dapat dirumuskan sebagai kemampuan yang mencerminkan kelancaran, keluwesan (fleksibilitas) dan orisinalitas dalam berpikir, serta kemampuan untuk mengelaborasi (mengembangkan, memperkaya, memperinci) suatu gagasan.

Berdasarkan teori di atas peneliti memahami bahwa kreativitas merupakan kemampuan yang dimiliki seseorang untuk menemukan dan menciptakan sesuatu yang sifatnya baru atau berupa gabungan dari hal-hal yang sudah ada sebelumnya dengan berbagai kombinasi yang unik dan menarik serta berguna bagi dirinya dan lingkungan sekitar.

Sesuai dengan tahapan perkembangan anak, karakteristik cara anak belajar, konsep belajar dan pembelajaran bermakna, maka kegiatan pembelajaran bagi anak kelas awal SD sebaiknya dilakukan dengan Pembelajaran tematik. Pembelajaan tematik adalah pembelajaran tepadu yang menggunakan tema untuk mengaitkan beberapa mata pelajaran sehingga dapat memberikan pengalaman bermakna kepada peserta didik. Tema adalah pokok pikiran atau gagasan pokok yang menjadi pokok pembicaraan.

Dengan tematik diharapkan akan memberikan banyak keuntungan, di antaranya: (1) Peserta didik mudah memusatkan perhatian pada suatu tema tertentu, (2) Peserta didik mampu mempelajari pengetahuan dan mengembangkan berbagai kompetensi dasar antar matapelajaran dalam tema yang sama, (3) pemahaman terhadap materi pelajaran lebih mendalam dan berkesan, (4) kompetensi dasar dapat dikembangkan lebih baik dengan mengkaitkan matapelajaran lain dengan pengalaman pribadi peserta didik, (5) Peserta didik mampu lebih merasakan manfaat dan makna belajar karena materi disajikan dalam konteks tema yang jelas, (6) Peserta didik lebih bergairah belajar karena dapat berkomunikasi dalam situasi nyata, untuk mengembangkan suatu kemampuan dalam satu mata pelajaran sekaligus mempelajari matapelajaran lain, (7) guru dapat menghemat waktu karena mata pelajaran yang disajikan secara tematik dapat dipersiapkaan sekaligus dan diberikan dalam dua atau tiga pertemuan, waktu selebihnya dapat digunakan untuk kegiatan remedial, pemantapan, atau pengayaan.

Pembelajaran tematik lebih menekankan pada keterlibatan siswa dalam proses belajar secara aktif dalam proses pembelajaran, sehingga siswa dapat memperoleh pengalaman langsung dan terlatih untuk dapat menemukan sendiri berbagai pengetahuan yang dipelajarinya. Melalui pengalaman langsung siswa akan memahami konsep-konsep yang mereka pelajari dan menghubungkannya dengan konsep lain yang telah dipahaminya. Teori pembelajaran ini dimotori para tokoh Psikologi Gestalt, termasuk Piaget yang menekankan bahwa pembelajaran haruslah bermakna dan berorientasi pada kebutuhan dan perkembangan anak.

Pembelajaran tematik lebih menekankan pada penerapan konsep belajar sambil melakukan sesuatu (learning by doing). Oleh karena itu, guru perlu mengemas atau merancang pengalaman belajar yang akan mempengaruhi kebermaknaan belajar siswa. Pengalaman belajar yang menunjukkan kaitan unsur-unsur konseptual menjadikan proses pembelajaran lebih efektif. Kaitan konseptual antar mata pelajaran yang dipelajari akan membentuk skema, sehingga siswa akan memperoleh keutuhan dan kebulatan pengetahuan. Selain itu, dengan penerapan pembelajaran tematik di sekolah dasar akan sangat membantu siswa, karena sesuai dengan tahap perkembangannya siswa yang masih melihat segala sesuatu sebagai satu keutuhan (holistik).

Beberapa ciri khas dari pembelajaran tematik antara lain: (1) Pengalaman dan kegiatan belajar sangat relevan dengan tingkat perkembangan dan kebutuhan anak usia sekolah dasar, (2) Kegiatan-kegiatan yang dipilih dalam pelaksanaan pembelajaran tematik bertolak dari minat dan kebutuhan siswa, (3) Kegiatan belajar akan lebih bermakna dan berkesan bagi siswa sehingga hasil belajar dapat bertahan lebih lama, (4) Membantu mengembangkan keterampilan berpikir siswa, (5) Menyajikan kegiatan belajar yang bersifat pragmatis sesuai dengan permasalahan yang sering ditemui siswa dalam lingkungannya, (6) Mengembangkan keterampilan sosial siswa, seperti kerjasama, toleransi, komunikasi, dan tanggap terhadap gagasan orang lain.

Dengan pelaksanaan pembelajaran dengan memanfaatkan tema ini, akan diperoleh beberapa manfaat yaitu: (1) Dengan menggabungkan beberapa kompetensi dasar dan indikator serta isi mata pelajaran akan terjadi penghematan, karena tumpang tindih materi dapat dikurangi bahkan dihilangkan, (2) Siswa mampu melihat hubunganhubungan yang bermakna sebab isi/materi pembelajaran lebih berperan sebagai sarana atau alat, bukan tujuan akhir, (3) Pembelajaran menjadi utuh sehingga siswa akan mendapat pengertian mengenai proses dan materi yang tidak terpecah-pecah, (4) Dengan adanya pemaduan antar mata pelajaran maka penguasaan konsep akan semakin baik dan meningkat. 
Sebagai suatu model pembelajaran di sekolah dasar, pembelajaran tematik memiliki karakteristik-karakteristik sebagai berikut: (1) Berpusat pada siswa. Pembelajaran tematik berpusat pada siswa (student centered), hal ini sesuai dengan pendekatan belajar modern yang lebih banyak menempatkan siswa sebagai subjek belajar sedangkan guru lebih banyak berperan sebagai fasilitator yaitu memberikan kemudahan-kemudahan kepada siswa untuk melakukan aktivitas belajar, (2) Memberikan pengalaman langsung. Pembelajaran tematik dapat memberikan pengalaman langsung kepada siswa (direct experiences). Dengan pengalaman langsung ini, siswa dihadapkan pada sesuatu yang nyata (konkrit) sebagai dasar untuk memahami hal-hal yang lebih abstrak, (3) Pemisahan matapelajaran tidak begitu jelas. Dalam pembelajaran tematik pemisahan antar mata pelajaran menjadi tidak begitu jelas. Fokus pembelajaran diarahkan kepada pembahasan tema-tema yang paling dekat berkaitan dengan kehidupan siswa, (4) Menyajikan konsep dari berbagai mata pelajaran. Pembelajaran tematik menyajikan konsep-konsep dari berbagai mata pelajaran dalam suatu proses pembelajaran. Dengan demikian, Siswa mampu memahami konsep-konsep tersebut secara utuh. Hal ini diperlukan untuk membantu siswa dalam memecahkan masalah-masalah yang dihadapi dalam kehidupan sehari-hari, (5) Bersifat fleksibel. Pembelajaran tematik bersifat luwes (fleksibel) dimana guru dapat mengaitkan bahan ajar dari satu mata pelajaran dengan mata pelajaran yang lainnya, bahkan mengaitkannya dengan kehidupan siswa dan keadaan lingkungan dimana sekolah dan siswa berada, (6) Hasil pembelajaran sesuai dengan minat dan kebutuhan siswa. Siswa diberi kesempatan untuk mengoptimalkan potensi yang dimilikinya sesuai dengan minat dan kebutuhannya, (7) Menggunakan prinsip belajar sambil bermain dan menyenangkan.

Tujuan dari penelitian ini adalah (1) untuk mendeskripsikan perencanaan pembelajaran tematik di kelas I SD Negeri 24 Sungai Pinyuh, (2) untuk mendeskripsikan pelaksanaan pembelajaran tematik di kelas I SD Negeri 24 Sungai Pinyuh, (3) untuk mendeskripsikan peningkatan kreativitas peserta didik pada pembelajaran tematik di kelas I SD Negeri 24 Sungai Pinyuh.

\section{MetOde PENELITIAN}

Metode penelitian adalah cara yang digunakan oleh peneliti dalam mengumpulkan data penelitiannya" (Suharsimi Arikunto 2008:16). Sementara menurut Iskandar (2009:18) metode adalah upaya untuk mengimplementasikan rencana yang sudah disusun dalam kegiatan nyata agar tujuan yang telah disusun tercapai secara optimal.

Dari beberapa teori tersebut peneliti memahami bahwa metode penelitian merupakan cara yang digunakan oleh peneliti dalam mengumpulkan data penelitiannya dengan tujuan untuk memecahkan masalah yang diteliti agar penelitian terarah sesuai dengan tujuan yang diharapkan. Penelitian ini menggunakan metode penelitian deskriptif. Penelitian deskriptif merupakan paparan (deskripsi) informasi tentang gejala, peristiwa, kejadian sebagaimana adanya (Suharsimi Arikunto, 2008:56).

Bentuk penelitian menurut teori Suharsimi Arikunto, Suharjono, dan Supardi (2008:2) menjelaskan Penelitian Tindakan Kelas (PTK) dengan memisahkan kata-kata yang tergabung didalamnya, sebagai berikut: (1) Penelitian menunjukkan pada suatu kegiatan mencermati suatu objek dengan menggunakan cara dan aturan metodologi tertentu untuk memperoleh data atau informasi yang bermanfaat dalam meningkatkan mutu suatu hal yang menarik minat dan penting bagi peneliti, (2) Tindakan menunjuk pada suatu gerak kegiatan yang sengaja dilakukan dengan tujuan tertentu. Dalam penelitian berbentuk rangkaian siklus kegiatan, (3) Kelas dalam hal ini tidak terikat pada pengertian ruang kelas, tetapi dalam pengertian yang lebih spesifik, seperti yang sudah lama dikenal dalam bidang pendidikan dan pengajaran, yang dimaksud dengan istilah kelas adalah peserta didik yang dalam waktu yang sama, menerima pelajaran yang sama dari seorang guru.

Menurut Mills (dalam Igak Wardhani, 2008:15) mendefinisikan penelitian tindakan kelas sebagai "Systematic Inquiry" (sistem inquiri) yang dilakukan oleh guru, kepala sekolah atau konselor sekolah untuk mengumpulkan informasi tentang berbagai praktek yang dilakukannya. Sementara menurut teori H.E. Mulyasa (2009:112) penelitian tindakan kelas merupakan suatu rangkaian siklus yang berkelanjutan, siklus-siklus tersebut terdapat informasi sebagai umpan balik (feed back) terhadap apa yang telah dilakukan oleh peneliti. Siklus tersebut terdiri dari perencanaan (planning), aktivitas (ackting), pengamatan (observing), dan refleksi (reflecting).

Berdasarkan beberapa teori tersebut dapat dipahami bahwa, penelitian tindakan kelas adalah penelitian yang dilakukan oleh guru di dalam kelasnya sendiri melalui refleksi diri dengan tujuan untuk memperbaiki kinerja sebagai guru sehingga hasil belajar peserta didik menjadi meningkat. Dalam penelitian ini menggunakan bentuk penelitian yaitu penelitian tindakan kelas menurut teori Suharsimi Arikunto Suharjono dan Supardi (2008:2).

Penelitian ini dilaksanakan pada kelas I Sekolah Dasar Negeri 24 Sungai Pinyuh, Kabupaten Pontianak. Adapun yang menjadi subjek penelitian adalah sebagai berikut: (1) Guru sebagai peneliti yang melakukan penelitian di kelasnya sendiri, yaitu kelas I Sekolah Dasar Negeri 24 Sungai Pinyuh, Kabupaten Pontianak, (2) Peserta didik sebagai subjek dalam pembelajaran tematik adalah peserta didik kelas I Sekolah Dasar Negeri 24 Sungai Pinyuh, Kabupaten Pontianak yang berjumlah 20 peserta didik, 12 orang laki-laki dan 8 orang perampuan.

Teknik pengumpulan data yang digunakan adalah Observasi langsung. Observasi dilaksanakan secara langsung oleh guru sebagai peneliti. Guru melaksanakan penelitian, diobservasi langsung oleh guru lain sebagai kollabolator. Untuk mengetahui sejauh mana kemampuan guru dalam merancang RPP tematik, melaksanakan pembelajaran tematik, menilai kreativitas peserta didik, serta nilai hasil belajar yang diperoleh peserta didik. 
Teknik pengukuran yang digunakan adalah mengisi tabel observasi kinerja guru dalam membuat RPP tematik dan mengukur kemampuan guru melaksanakan pembelajaran tematik. Mengukur kreativitas peserta didik selama pembelajaran tematik berlangsung dengan lembaran kreativitas belajar peserta didik, serta mengukur keberhasilan peserta didik dalam pembelajaran tematik.

Proses pengumpulan data dilakukan untuk mengukur kemampuan yang diperoleh guru dan peserta didik dalam pembelajaran tematik untuk mengukur peningkatan yang diperoleh selama penelitian. Berdasarkan teknik pengumpulan data di atas, maka alat pengukur data adalah sebagai berikut: (1) Lembar observasi kemampuan guru merancang Rencana pelaksanaan pembelajaran tematik, (2) Lembar observasi kemampuan guru melaksanakan pembelajaran tematik, (3) Lembar observasi kreativitas peserta didik dalam proses pembelajaran tematik, (4) Soal tes hasil belajar peserta didik. Jenis tes adalah tes tertulis.

Rencana tindakan dalam penelitian tindakan kelas ini dilaksanakan dalam 2 (dua) siklus . Setiap siklus memiliki 4 tahap yaitu : perencanaan (planning), implementasi / tindakan, pengamatan (observation) dan refleksi (reflection).

Prosedur Penelitian: Penelitian dimulai dari guru merefleksi diri mengenai proses pembelajaran tematik yang dilakukan selama ini. Selanjutnya guru merancang tindakan siklus I, melaksanakan tindakan dari perencanaan yang telah dilakukan pada siklus I, melakukan observasi dari pengamatan pada siklus I, kemudian melakukan refleksi dari hasil pengamatan tersebut, baik hasil pengamatan terhadap guru membuat RPP tematik, melaksanakan pembelajaran tematik, maupun kreativitas peserta didik dalam pembelajaran tematik, serta hasil akhir dari pembelajaran tersebut sebagai dampak dari proses pembelajaran tematik. Hal ini menjadi acuan selanjutnya, apakah penelitian ini akan dilanjutkan pada siklus selanjutnya, atau telah berhasil. Jika hasil yang diperoleh belum mencapai kreteria ketuntasan minimal, maka penelitian akan di lanjutkan.

Siklus I, Perencanaan: (1) Peneliti membuat rencana pembelajaran tematik penjumlahan dan pengurangan di kelas I SD, (2) Peneliti membuat soal penjumlahan dan pengurangan di kelas I SD, (3) Selain itu juga dipersiapkan penghargaan yang akan diberikan kepada peserta didik yang berprestasi, (4) Peneliti membuat lembar observasi untuk peserta didik dan guru mengamati sistuasi dan kondisi sebelum berlangsungnya kegiatan pembelajaran tematik, (5) Peneliti membuat alat evaluasi. Implementasi/tindakan: (1) Peneliti (guru) menjalankan rencana pembelajaran tematik, (2) Peneliti (guru) memberikan soal secara lisan kepada peserta didik yang dilakukan secara interaktif, (3) Peneliti (guru) memberikan tugas kepada peserta didik berupa soal, (4) Peneliti (guru) berkeliling membantu peserta didik yang mengalami kesulitan menyelesaikan tugas. Observasi/evaluasi: Observasi pada siklus I dilakukan peneliti sebagai kolabolator, observasi pada penelitian ini dilakukan terhadap kreativitas peserta didik. Evaluasi pada siklus I dilakukan dengan cara memberi tes kepada peserta didik untuk dikerjakan secara individu. Evaluasi dilaksanakan di akhir pertemuan pada siklus I. Refleksi: Refleksi merupakan analisis hasil observasi dan hasil tes. Refleksi pada siklus I dilaksanakan segera setelah tahap implementasi/tindakan dan obervasi selesai. Berdasarkan hasil observasi dan hasil tes siklus I. Jika sudah memenuhi indikator penelitan yang telah ditetapkan maka penelitian dihentikan, dan jika belum memenuhi indikator penelitian yang telah ditetapkan maka penelitian dilanjutkan ke siklus.

Siklus II, Perencanaan: (1) Peneliti membuat rencana pembelajaran tematik materi penjumlahan dan pengurangan berdasarkan hasil pada refleksi siklus I, (2) Peneliti membuat soal tematik, (3) Peneliti membuat pembelajaran tematik yang didesain berdasarkan dari hasil siklus I, selain itu juga, disiapkan penghargaan yang akan diberikan kepada peserta didik yang berprestasi, (4) Peneliti membuat lembar observasi untuk peserta didik dan guru, untuk mengamati situasi dan kondisi selama berlangsungnya kegiatan pembelajaran tematik. Implementasi/tindakan: (1) Peneliti (guru) mempelajari rencana pembelajaran tematik, (2) Peneliti (guru) memberikan soal secara lisan kepada peserta didik yang dilakukan secara interaktif, (3) Peneliti (guru) berkeliling membantu peserta didik yang mengalami kesulitan menyelesaikan tugas, (4) Peneliti (guru) memberikan soal sebagai kuis siklus tindakan II. Observasi dan evaluasi: Observasi pada siklus II merupakan kegiatan untuk pengamatan perbaikan dari observasi dan refleksi dari siklus I. Obeservasi dilakukan terhadap kreativitas peserta didik. Evaluasi pada siklus II dilaksanakan dengan cara memberikan tes pada peserta didik untuk dikerjakan secara individu. Tes dilakukan diakhir pertemuan siklus II. Refleksi: Refleksi pada siklus II dilakukan setelah implementasi/tindakan dan observasi selesai. Berdasarkan dari hasil obeservasi dan hasil evaluasi pembelajaran tematik siklus I serta hasil angket sikap peserta didik terhadap pembelajaran tematik, maka dapat ditarik kesimpulan bahwa penelitian telah berhasil karena memenuhi indikator penelitian yang telah ditetapkan.

Sebagai tolak ukur keberhasilan pelaksanaan penelitian tindakan kelas ini dapat dilihat dari: (1) Meningkatnya hasil belajar peserta didik dengan rata-rata hasil belajarnya minimal 60, (2) Meningkatnya kreativitas belajar peserta didik secara aktif dalam proses pembelajaran tematik, yang aktif minimal 60.

Penilaian kinerja guru pada siklus I dan II yang dinilai oleh teman sejawat (guru kolaborator) diberikan oleh persamaan yang dikemukakan oleh Ali (2011: 50) sebagai berikut:

$$
\text { Jumlah }=\frac{\text { Skor yang diperoleh }}{\text { Jumlah skor total }} \times 100 \%
$$

Dengan Skor 4 adalah baik sekali, skor 3 adalah baik, skor 2 adalah cukup dan skor 1 adalah kurang. Dan keterangan nilai adalah: $75,01 \%$ sampai $100 \%$ adalah sangat baik, $50,01 \%$ sampai $75,00 \%$ adalah baik, $25,01 \%$ sampai $50,00 \%$ adalah cukup baik, $0,00 \%$ sampai $25,00 \%$ adalah kurang baik. 
Hasil belajar peserta didik dengan melihat hasil perbandingan belajar pada siklus I dan siklus II, dengan mempresentasikan hasil rata-ratanya, seperti yang dikemukakan oleh Ali (2001: 18) dengan rumus :

$$
\mathrm{X} \%=\frac{n}{N} \times 100 \%
$$

Dengan $\mathrm{X} \%$ adalah persentase hasil hitung, $\mathrm{n}$ adalah jumlah peserta didik yang memperoleh nilai tertentu dan $\mathrm{N}$ adalah jumlah seluruh peserta didik. Dengan keterangan nilai: $75,01 \%$ sampai $100 \%$ adalah sangat baik, 50,01\% sampai
$75,00 \%$ adalah baik, $25,01 \%$ sampai $50,00 \%$ adalah cukup baik, $0,00 \%$ sampai $25,00 \%$ adalah kurang baik.

\section{HASIL DAN PEMBAHASAN}

\section{Hasil Penelitian}

Kinerja guru pada siklus I dan II yang dinilai oleh teman sejawat (guru kolaborator) diberikan pada tabel berikut ini:

Tabel 1. Hasil Observasi terhadap Kinerja Guru pada Siklus I dan II

\begin{tabular}{lcc}
\hline & Aspek yang Dinilai & \multicolumn{2}{c}{$\begin{array}{c}\text { Siklus I } \\
\text { Pertemuan ke }\end{array}$} & $\begin{array}{c}\text { Siklus } \\
\text { II }\end{array}$ & I & II \\
\cline { 2 - 3 } $\begin{array}{c}\text { Persiapan sebelum pelajaran di mulai. } \\
\text { a. Kesiapan ruang belajar. }\end{array}$ & 2 & 2 \\
b. Kesiapan sumber dan media pembelajaran tematik. & 2 & 3
\end{tabular}

Kegiatan awal

Menyampaikan tujuan dan memotivasi peserta didik.

a. Melakukan kegiatan appersepsi dan memotivasi peserta didik, curah pendapat tentang benda di sekitar.

b. Menyampaikan tujuan pembelajaran tematik yang akan dicapai.

c. Membuat kesepakatan tentang tema.

$\begin{array}{lll}2 & 3 & 4 \\ 3 & 3 & 3 \\ 3 & 3 & 3\end{array}$

Kegiatan int

1. Menyampaikan informasi.

a. Menjelaskan materi pelajaran sesuai tema dan langkah-langkah pembelajaran tematik yang akan dilaksanakan dengan bahasa yang baik.

b. Memberikan kesempatan peserta didik maju ke depan mengamati gambar benda.

c. Memotivasi peserta didik memberikan penafsiran terhadap gambar, mengungkapkan masalah dan mengutarakan gagasan.

d. Memberikan kesempatan pada peserta didik menggunakan media untuk mengidentifikasi benda dan menghitung jumlahnya.

e. Membimbing peserta didik agar senang melibatkan diri dalam tugas-tugas dan dapat memberikan keputusan.

f. Melaksanakan pembelajaran tematik.

2. Mengorganisasi peserta didik.

a. Membimbing peserta didik.

b. Melaksanakan pembelajaran tematik yang menyenangkan.

3. Membantu belajar peserta didik

a. Membimbing peserta didik dalam mengerjakan tugas agar dapat menghargai waktu dan bekerja lebih cepat.

b. Membimbing peserta didik agar dapat mengembangkan gagasan.

4. Mengetes materi

a. Melaksanakan refleksi tentang materi pelajaran bersama-sama.

b. Memberikan kesempatan menyajikan hasil kerjanya dan memberikan penilaian.

5. Memberikan penghargaan

a. Memberikan penghargaan/penguatan.

b. Menyimpulkan materi pelajaran melibatkan peserta didik.

Kegiatan akhir

a. Melaksanakan evaluasi

b. Melaksanakan tindak lanjut

c. Penutup

Jumlah 
Pada penelitian siklus I dan II, observasi dilakukan oleh pengamat untuk mengamati pelaksanaan tindakan dengan menggunakan lembar observasi kreativitas peserta didik. Berdasarkan hasil penelitian pada siklus I dan II peningkatan kreativitas peserta didik kelas I Sekolah Dasar Negeri 24 Sungai Pinyuh dapat dideskripsikan pada Tabel 2.

Perkembangan kreativitas peserta didik berdasarkan jumlah peserta didik yang melakukan kreativitas per siklus diperlihatkan pada Gambar 1.
Tabel 2. Rekapitulasi Hasil Observasi Kreativitas Peserta didik

\begin{tabular}{lccc}
\hline \multirow{2}{*}{ Aspek yang diobservasi } & \multicolumn{2}{c}{$\begin{array}{c}\text { Siklus I } \\
\text { Pertemuan ke }\end{array}$} & \multirow{2}{*}{ Siklus } \\
\cline { 2 - 3 } & II & II & \\
\hline Menafsirkan gambar/cerita & $55 \%$ & $65 \%$ & $70 \%$ \\
Senang melibatkan diri & $65 \%$ & $70 \%$ & $85 \%$ \\
dalam tugas-tugas & $30 \%$ & $40 \%$ & $50 \%$ \\
Bekerja lebih cepat & \multicolumn{2}{c}{$\mathbf{5 4 , 2 \%}$} & $\mathbf{6 8 , 3 \%}$ \\
\hline Rata-rata & \multicolumn{3}{c}{} \\
\hline
\end{tabular}

\section{Jumlah Peserta \\ Didik}

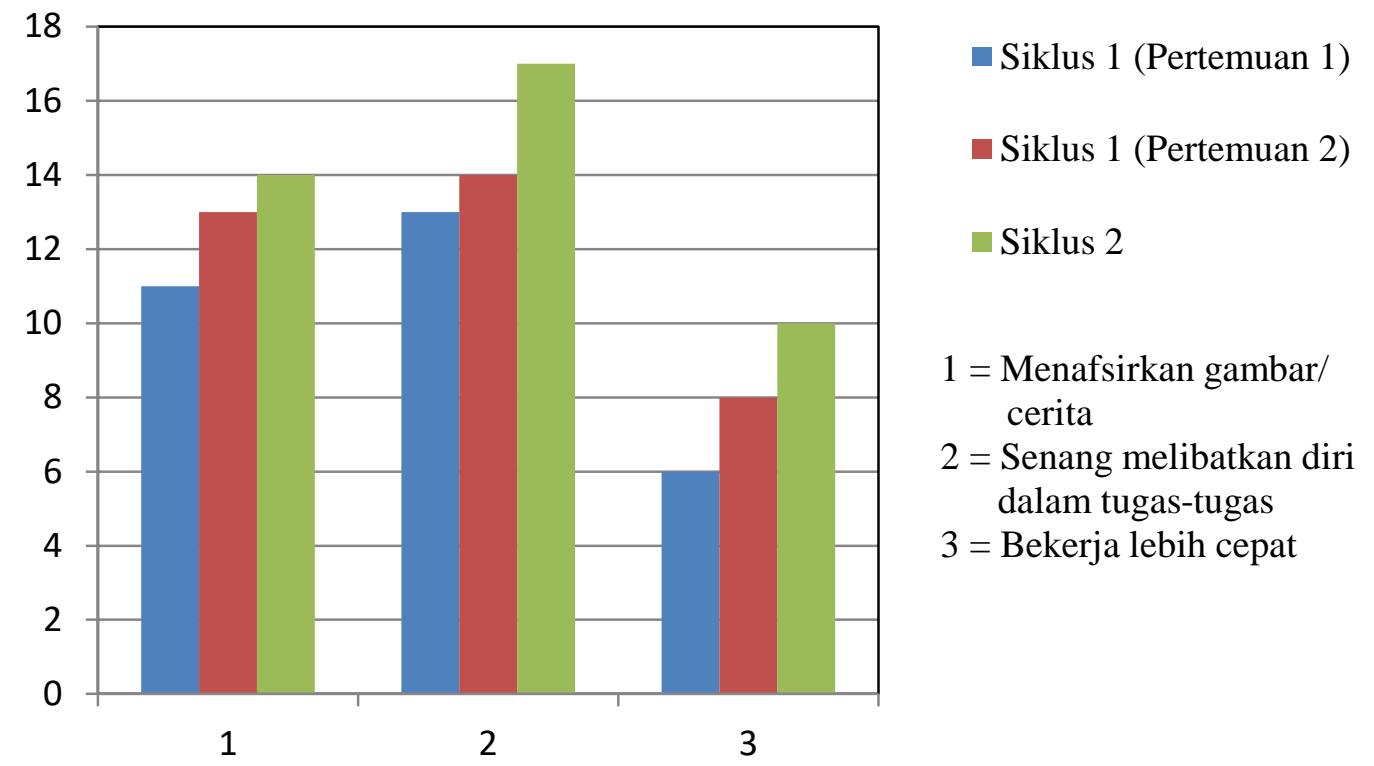

Gambar 1. Perkembangan Kreativitas Peserta Didik Per Siklus

\section{Pembahasan}

Berdasarkan hasil pengamatan kolaborator pada tabel 1, bahwa kinerja guru pada siklus I dihitung dengan persamaan penilaian kinerja guru sebagaimana tercantum pada bagian metode diberikan oleh penilaian kinerja guru $=(57,5 / 88) \mathrm{x}$ $100 \%=65,3 \%$ (kategori Baik). Sedangkan pada siklus II, penilaian kinerja guru $=(70 / 88) \times 100 \%=79,6 \%$ (kategori sangat baik).

Berdasarkan data yang diperoleh dari hasil observasi pada tabel 2. di atas mengenai kreativitas peserta didik pada siklus I yang dihitung dengan rumus persentase dapat diungkapkan sebagai berikut: (a) Peserta didik yang mampu menafsirkan gambar, yang diperoleh dari hasil pengamatan peneliti pada siklus I pertemuan I dengan menggunakan lembar observasi tingkat kreativitas peserta didik mencapai 55\% dengan, pada pertemuan II tingkat kreativitas peserta didik mencapai $65 \%$, dengan kategori baik, (b) Peserta didik senang melibatkan diri dalam tugas-tugas, diperoleh dari hasil pengamatan peneliti pada siklus I pertemuan I dengan menggunakan lembar observasi tingkat kreativitas peserta didik mencapai $65 \%$, pada pertemuan II tingkat kreativitas peserta didik mencapai 70\%, dengan kategori baik, (c) Peserta didik dapat bekerja lebih cepat dari anak-anak yang lain, diperoleh dari hasil pengamatan peneliti pada siklus I pertemuan I dengan menggunakan lembar observasi, tingkat kreativitas peserta didik mencapai $30 \%$ pada pertemuan II tingkat kreativitas mencapai $40 \%$ dengan kategori cukup baik. Berdasarkan data yang diperoleh pengamat, tingkat kreativitas peserta didik pada siklus I 54,2\% dengan kategori baik.

Berdasarkan data yang diperoleh dari hasil observasi pada tabel di atas mengenai kreativitas peserta didik pada siklus II yang dihitung dengan rumus persentase dapat diungkapkan sebagai berikut: (1) Peserta didik mampu menafsirkan gambar diperoleh dari hasil pengamatan pada siklus II dengan menggunakan lembar observasi tingkat kreativitas peserta didik mencapai $70 \%$, (2) Peserta didik senang melibatkan diri dalam tugas-tugas di peroleh dari hasil pengamatan pada siklus II dengan menggunakan lembar 
observasi tingkat kreativitas peserta didik mencapai 85\%, (3) Peserta didik bekerja lebih cepat dari anak-anak yang lain diperoleh dari hasil pengamatan pada siklus II dengan menggunakan lembar observasi tingkat kreativitas peserta didik mencapai 50\% kategori cukup baik. Berdasarkan data yang diperoleh pengamat, tingkat kreativitas peserta didik pada siklus I 68,3\% dengan kategori baik.

Perkembangan peningkatan kreativitas peserta didik yang diperlihatkan pada gambar 1, memberikan gambaran bahwa semakin meningkat jumlah peserta didik yang melakukan kreativitas dari siklus I ke siklus II. 3 kreativitas yang telah diamati pada penelitian tindakan kelas ini adalah kreativitas menafsirkan gambar/cerita, senang melibatkan diri dalam tugas-tugas dan bekerja lebih cepat.

Pada pembelajaran tematik, peneliti mengambil tema "Rumahku Bersih" yang telah berhasil meningkatkan kreativitas peserta didik berupa menafsirkan gambar/cerita, senang melibatkan diri dalam tugas-tugas dan bekerja lebih cepat. Pembelajaran Tematik adalah pembelajaran yang berkaitan dengan suatu tema yang berupa subjek atau topik yang dijadikan pokok pembahasan. Tema tersebut dijadikan dasar untuk berbagai mata pelajaran, termasuk Bahasa Indonesia, Agama, Matematika dan lain-lain.

\section{KESIMPULAN DAN SARAN}

Berdasarkan hasil penelitian dan pembahasan di dalam penelitian tentang peningkatan kreativitas peserta didik dalam pembelajaran tematik di kelas I Sekolah Dasar Negeri 24 Sungai Pinyuh dapat disimpulkan sebagai berikut: (1) Perencanaan pembelajaran tematik di kelas I SDN 24 Sungai Pinyuh telah didasarkan pada Kurikulum Tingkat Satuan Pendidikan (KTSP)/ Silabus, Permen Nomor 41 tahun 2007 dan Rencana Pelaksanaan Pembelajaran (RPP) Tematik yang dibuat, (2) Pelaksanaan pembelajaran tematik di kelas I SDN 24 Sungai Pinyuh berdasarkan dari RPP dan Peraturan Menteri (Permen) Nomor 41 tahun 2007. Kegiatan dilaksanakan dengan baik. Ini dapat dilihat hasil observasi kinerja guru oleh teman sejawat secara kontekstual, demokratis, PAIKEM dan berbasis pada Cara Belajar Siswa Aktif (CBSA), (3) Rata-rata 3 Kreativitas peserta didik (menafsirkan gambar/cerita, senang melibatkan diri dalam tugas-tugas, bekerja lebih cepat) pada pembelajaran tematik di kelas I SDN 24 sungai Pinyuh pada siklus I sebesar 54,2\% (kategori baik) sedangkan siklus II sebesar 68,3\% (kategori baik). Kreativitas peserta didik dari siklus I ke siklus II mengalami peningkatan sebesar 14,2\%. Sehingga dapat disimpulkan bahwa pada pembelajaran tematik dapat meningkatkan kreativitas peserta didik kelas I SDN 24 Sungai Pinyuh.

Berdasarkan hasil penelitian dan pembahasan maka peneliti mengemukakan beberapa saran sebagai berikut: (1) Dalam pelaksanaan pembelajaran tematik sebaiknya guru dapat mengkondisikan kelas sehingga peserta didik mendapatkan pengalaman belajar yang menyenangkan dan bermakna, (2) Sebaiknya guru selalu membimbing peserta didik pada setiap kegiatan sehingga semua aspek kreativitas peserta didik dapat muncul, (3) Menciptakan komunikasi multiarah dan suasana demokratis sehingga peserta didik merasa senang dalam belajar.

\section{DAFTAR PUSTAKA}

Akhmad Sudrajat. 2008. Penilaian Hasil Belajar. (Online) (http://akhmadsudrajat.wordpress.com/2008/05/01/pe nilaian-hasil-belajar/, diakses pada tanggal 14 Januari 2017).

Amirul Hadi., Haryono. 2005. Metodologi Penelitian Pendidikan. Bandung: C. Pustaka Setia.

BSNP. 2008. Kurikulum Tingkat Satuan Pendidikan Sekolah Dasar Kelas I. Jakarta: Departemen Pendidikan Nasional.

Daryanto. 2009. Panduan Proses Pembelajaran Kreatif dan Inovatif. Jakarta. Publisher.

Ida Rianawati. 2011. Pembelajaran Kreatif I. (Online) (http://ida-rianawaty.blogspot.com/2011/02)modelpembelajaran-kreatif-produktif.html, diakses pada tanggal 7 Januari 2017).

Igak Wardani. 2008. Penelitian Tindakan Kelas. Jakarta: Depdiknas.

Kurnia., Inggridwati., dkk. 2007. Perkembangan Peserta Didik. Jakarta: Direktorat Jendral Pendidikan Tinggi Departemen Pendidikan Nasional.

Massofa. 2007. Ruang Lingkup dan Proses Pembelajaran. (Online) (http://massofa.wordpress.com/2007/12/21/ruanglingkup-dan-proses-pembelajaran-ips/, diaskes pada tanggal 07 Januari 2017).

Mulyasa. 2009. Praktek Penelitian Tindakan Kelas. Bandung: PT. Remaja Rosdakarya.

Nanang Hidayat. 2010. Karakteristik dan Perkembangan Belajar.

(Online)

(http://nananghidayat17.blogspot.com/2010/04/karakt eristik-dan-perkembangan-belajar.html, diaskes pada tanggal 10 Januari 2017).

Reni Akbar., Hawadi., Sihadi Darmo Wihardjo., \& Mardi Wiyono. 2001. Kreativitas. Jakarta: PT. Gramedia Widiasarana.

Sirojudin. 2004. Belajar Matematika SD Kelas I. Bandung: PT. Sarana Pancakarya Nusa.

Sugiyono. 2009. Metode Penelitian Kuantitatif Kualitatif. Bandung: Alpabeta.

Suharsimi Arikunto., Suhardjono., \& Supardi. 2008. Penelitian Tindakan Kelas. Jakarta: PT. Sinar Grafika.

Syaiful Bahri Djamarah., Aswan Zain. 2006. Strategi Belajar Mengajar. Jakarta: PT. Rineka Cipta.

Trianto. 2010. Model Pembelajaran Tematik. Jakarta: PT. Prestasi Pustaka Raya.

Utami Munandar. 2009. Pengembangan Kreativitas Anak Berbakat. Jakarta: Rineka Cipta. 
Watidana.

2010.

Student.

(Online)

(http://watidana.student.unn.ac.id/Pebelajaran-

Kreatif, diakses pada tanggal 22 Januari 2017).

Wawan Junaidi. 2010. Jenis-Jenis Tes Hasil Belajar. (Online) (http://wawan-junaidi.blogspot.com/jenisjenis-tes-hasil-belajar.html, diakses pada tanggal 10 Januari 2017). 